\title{
A STUDY ON TRANSPORT PLANNING SOLUTIONS TO MEET THE DEVELOPMENT OF LOGISTICS SERVICES, A CASE IN CAI MEP-THI VAI PORT
}

\author{
Van Tai Pham \\ College of Foreign Economic Relations (COFER), Vietnam. \\ Email: phamvantai@gmail.com
}

Article History: Received on $21^{\text {st }}$ October 2019, Revised on $02^{\text {nd }}$ February 2020, Published on $28^{\text {th }}$ February 2020

\begin{abstract}
Purpose of the study: With the goal of setting up a superior logistics center, it is guaranteed to minimize transportation costs for businesses in the region in order to form reasonable transportation routes, within and outside the guaranteed area. Improve the output of goods through and reduce social costs, in accordance with the planning of the transportation system, improve socio-economic efficiency in goods circulation.
\end{abstract}

Methodology: This study uses statistical methods - data analysis, survey analysis, trend approach to forecast such as goods demand through ports, assess the nature of the problem and find specific solutions to devise optimal planning solutions.

Main Findings: Transport infrastructure directly affects logistics performance, particularly on time, cost, reliability, and safety of this service, thereby affecting the growth rate of the economy in general and the business efficiency of enterprises in particular. Therefore, in order to meet the fast development of Cai Mep-Thi Vai logistics and port system, the transport infrastructure must be concerned, planned, and deployed in a synchronized and proper manner.

Applications of this study: The Cai Mep-Thi Vai port area being invested and built and developed will be of utmost importance in Vietnam, with access to international maritime routes, connecting with existing wharves to form a continuous port system serving the dynamic economic development centers of the southern and international regions.

Novelty/Originality of this study: The problems of port logistics and transport infrastructure to serve logistics. Provide some general theoretical issues about transportation for port logistics services. Also basing on foreign experiment and regional lessons to evaluate the existence of transport infrastructure for logistics services in Cai Mep-Thi Vai port area; point out the shortcomings and inadequacies of transport infrastructure for logistics.

Keywords: Transport Planning Solution, Internal Traffic, Port Logistics, Transport Infrastructure, Cai Mep-Thi Vai port.

\section{INTRODUCTION}

The logistics industry plays an increasingly important role in modern economies and has a great influence on the economic development of countries and the world. If taken from a holistic perspective, logistics is an economic link across almost the entire process of production, circulation, and distribution of goods (Witkowski, 2017). Each activity in the chain has a position and accounts for a certain cost. According to the statistics, logistics spending alone accounts for $10 \div 15 \%$ of GDP of most major countries in Asia and the Americas. Therefore, if the efficiency of logistics activities is improved, it will make an important contribution to socio-economic efficiency (Agrawal, Singh, \& Murtaza, 2015).

Logistics infrastructure is understood as the physical and spatial structural resources in the logistics system, including warehousing, resources, suppliers of input materials (national and international), manufacturers, consumers. According to (V. T. Pham, 2019), infrastructure is considered to be economic infrastructure, railway, road transport, ports, aviation, telecommunications and energy (Hoang \& Pham, 2018). Thus, logistics infrastructure is understood as a comprehensive of physical, technical and architectural factors that play a fundamental role in logistics activities in general and logistics services in particular. Regular logistics infrastructure is divided into two groups, "hardware" infrastructure and "software" infrastructure (Phuong, 2019).

Transport infrastructure plays a foundation role as a very important physical premise for all activities of transporting and circulating goods (Álvarez-SanJaime, Cantos-Sánchez, Moner-Colonques, \& Sempere-Monerris, 2013). Without a complete and standardized road system, vehicles like cars, trains, airplanes, etc. will not be able to function properly, not guaranteeing safety and speedy when transporting passengers and goods (Govindan \& Soleimani, 2017). Therefore, the quality of transport infrastructure works is a prerequisite affecting the quality of transport activities in particular and affecting the development of socio-economic production in general. A growing society, the increasing demand for transport requires transport infrastructure to be properly invested both in quantity and quality (X. P. Nguyen, 2019).

Transport infrastructure directly affects logistics performance, particularly on time, cost, reliability, and safety of this service, thereby affecting the growth rate of the economy in general and the business efficiency of enterprises in particular. According to the average statistics in the US and other countries, the cost of trade logistics includes transport costs, inventory costs, and administration costs, of which transport costs account for 50 - 60\% (Hoang \& Pham, 2019). Thus, transport is the most important activity in logistics activities, accounting for about $1 / 3$ to $2 / 3$ of logistics costs of businesses (C. Wang, Lu, Xi, \& Nguyen, 2019). The development of a system of maritime transport infrastructure needs to focus first on building seaports, inland logistics-port centers, inland container depot (ICD), warehousing, transport hubs and the 
development of maritime transport and cargo handling facilities, especially container handling facilities. According to experts from other countries, the investment and development policy for the sea transport system should be conducted synchronously with the development of road, railway, airway, and inland waterway infrastructure (C.-N. Wang, Day, Lien, \& Chien, 2018).

For businesses, logistics has a huge role. Logistics helps businesses solve both inputs and outputs effectively, thereby helping businesses reduce costs, increase competitiveness in the market (T. T. Nguyen, 2016). On the other hand, logistics also helps businesses improve management efficiency, reduce costs to improve competitiveness (Panigrahi, Kar, Fen, Hoe, \& Wong, 2018). With a favorable geographical position, Ba Ria - Vung Tau is eligible to become a transit point for goods and perform logistics services in the region. Potential, advantages of port services, logistics services will be increasingly developed when important projects such as Cai Mep - Thi Vai inter-port road, expanded highway 51, Ho Chi Minh City Long Thanh - Vung Tau highway, Ho Chi Minh City - Bien Hoa - Vung Tau and Long Thanh airport, ... invested synchronously. Currently, Ba Ria - Vung Tau is also focusing on planning the development of urban systems, such as Vung Tau City, Phu My City, Ba Ria City, and in the future will connect the cities (X. P. Nguyen, 2019). This town together in a unified economic space, forming a synchronous economic - industrial corridor - seaport, aiming to become a port city in the future. The developing Ba Ria - Vung Tau seaport system will be of the utmost importance in Vietnam, with access to international maritime routes, connecting with Dong Nai and Ho Chi Minh seaport systems, forming a continuous port system associated with dynamically developing economic centers, with granary in the Mekong Delta (Khoa Pham \& Phuong Nguyen, 2019).

However, there is a fact that has existed for many years: Ba Ria - Vung Tau focused on developing the seaport system. It has not paid attention to developing and exploiting effectively types of logistics services, and connecting infrastructure (Shinde \& Mane, 2019). The establishment and development of a strong port system in Ba Ria - Vung Tau province, including deep-sea port system on Thi Vai River, which will inevitably increase rapidly container cargo volume of the South through the Vung Tau port system in the future as forecasted, dragging on the strong development of different types of logistics services. But if logistics services and port services are not given appropriate attention, growing slowly and not keeping up with the rapid development of the seaport system in the current period, Ba Ria - Vung Tau does not just miss the opportunity to declare (Springer, 2018). The potential of this important development field will not meet the goals of socio-economic development in the direction of raising the proportion of services. In particular, transport infrastructure directly affects logistics efficiency, particularly on time, cost, reliability, and safety of this service, thereby affecting the growth rate of the economy in general and the business efficiency of enterprises in particular (Phuong, 2019). Therefore, in order to meet the fast development of Cai Mep Thi Vai logistics and port system, the transport infrastructure must be concerned, planned and deployed in a synchronized and proper manner (Demırbas, 2016).

In the logistics infrastructure system, seaports are considered the most important and indispensable link. Therefore, the shortage or weakness of the seaport and logistics services after the port will greatly affect logistics activities. Cai Mep - Thi Vai area has a large number of ports but mainly has limited loading and unloading capacity. Moreover, seaports are not effectively connected with modern transportation systems, especially the railway system with ports and logistics centers, so the port's cargo transportation often conflicts with urban traffic. Meanwhile, the demand for cargo transportation by containers as well as many other types of vehicles and container port demand increased. The investment is scattered, lacking in focus, without long-term planning, logistics centers are not included in the international seaport construction plans but only in the logistics function area inside the port, some ports do not appreciate the amount of cargo throughput so that many seaports only operate at $20 \%-30 \%$ of capacity.

The contents will be presented in this article include: Understanding the current state planning of the area, surrounding routes, points of attraction - generating goods. Survey on transport, the situation of the traffic accident, socio-economic ... of the main roads and industrial parks under study. Forecasting flow, cargo flow, the impact of transportation on logistics activities. Proposing transport planning solutions to meet Cai Mep Ha port logistics service development, Ba Ria - Vung Tau province.

\section{CURRENT SITUATION OF TRAFFIC INFRASTRUCTURE TO MEET LOGISTICS SERVICE DEVELOPMENT}

\section{Current status of the transport system to meet the development of logistics services in Ba Ria-Vung Tau}

The planning area of the logistics center at Cai Mep Ha is located in the south of Phu My town surrounded by Rach Ong, Rach Cai Mep, Rach Da Giang, and Nhat River. According to the statistics of the Department of Natural Resources and Environment of Ba Ria - Vung Tau province, the land area is about 1,236 ha, including - Protective forest land: 816.2 ha; Salt making land: 24.8 ha; Mud dump: 66.9 ha; Rivers, lakes, and ponds: 285.2 hectares; Unused flat land: 42.9 ha. Proposing the planning idea, it is necessary to analyze on the basis of the natural conditions of the project status, with the majority of the area being mangrove vegetation systems, along with the dense river system and rivers, we propose to develop a planning idea for the project on the basis of respect and maximum protection of the existing vegetation and canal system. 


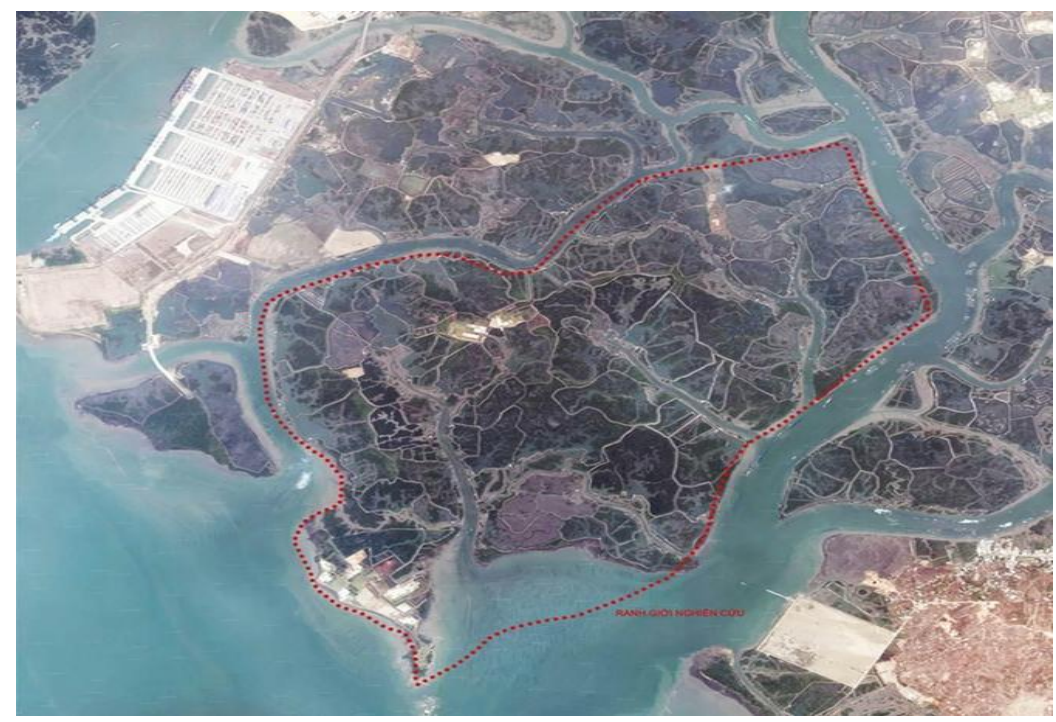

Figure 1: The situation of logistics centers and Cai Mep Ha port

Cai Mep Ha port area in Ba Ria Vung Tau province is the gateway of the key economic region of the South, the center of transshipment of import and export goods of the southern key economic region, the South Central Highlands, the Mekong Delta, Mekong sub-region with countries in Southeast Asia and the world, with convenient sea, river and air systems. In recent years, Ba Ria-Vung Tau province has been focusing on building industrial parks such as Dong Xuyen, Phuoc Thang, Thi Vai Port, My Xuan, Phu My, and Chau Duc industrial parks, thermal power plants, gas plants, etc. but especially the infrastructure system and roads of the region closely linked to the Southern key economic region and Ba Ria Vung Tau province has been invested to build and renovate and upgrade one step, creating a new face for a major tourist center of the country, which has attracted more and more goods and passengers. The road transport system includes routes: Ho Chi Minh City - Long Thanh - Dau Giay highway; Highway 51; Highway 55; Highway 56; Provincial road system (Including 45 routes with a total length of about $413 \mathrm{~km}$ ). Waterway transport system includes: Waterway network (including 22 river-canals that can exploit water transport with a total length of about 166km); Port system (with 23 ports under central management with a total length of $15,036 \mathrm{~m}$ of wharves, an area of about 2,452 ha); Inland port-wharf system (with a total of 34 ports and inland wharves, including 27 wharves for fishing, 4 construction materials wharves, and 3 passenger wharves)

\section{A general assessment of the current situation and demand for transport infrastructure}

\section{Road traffic network}

Traffic density is currently mainly concentrated on the corridor of National Highway 51 (NH.51) and Ho Chi Minh City Long Thanh - Dau Giay expressway, the organization of traffic on the routes is not suitable, there are many accidents. Traffic density in the direction of NH.56 and NH.55 is also at overload (Nardin, Woodcock, \& Fagherazzi, 2016). Traffic density on other roads in the province is low due to underdeveloped infrastructure and socio-economic development in the area (currently concentrated in the West near NH.51). In the area, there is 1 expressway and 3 National highways which are very reasonably distributed (Ho Chi Minh City - Long Thanh - Dau Giay highway and NH.51 to provinces in the West and Northwest; NH.56 to the Northern provinces; NH.55 to the eastern provinces) (Hao Dong \& Phuong Nguyen, 2019). The provincial road network has been forming the North-South and East-West axes, combined with the National routes, creating a continuous network spread over the area. Provincial roads: 42 routes are about $413 \mathrm{~km} \mathrm{long,} \mathrm{asphalted} \mathrm{about}$ $94 \%$, most of them reach grade IVB.

\section{Waterway transportation network}

The main network of rivers and canals has a total length of $166 \mathrm{~km}$, but has only been managed and operated about $92 \mathrm{~km}$ and about $120 \mathrm{~km}$ of coastal waterways. The potential for water transport is huge: The ability to link waterway with other provinces in the country regionally and internationally is very convenient. Some deep and wide rivers in this area are very favorable for the development of a system of deep-sea ports and seaports such as Cai Mep-Thi Vai and Dinh rivers (Dong \& Phan, 2019). The system of inland waterway ports has developed spontaneously, especially the fishing port system (Orchard, Stringer, \& Quinn, 2015). In general, the port and wharf system has not had appropriate investment, and there has been no unified management in terms of the State. The investment in preservation, repair, and embankment of the wharf system, dredging and clearing the channel has not been synchronized. Therefore, the attraction of capital sources is very limited.

\section{Assess the current status of transport}

In Ba Ria-Vung Tau province, there are currently three types of transport: trucking, inland water transport, air transport, 
and iron-wheel transport. Average freight growth (2010-2018) is about $18 \%$ per year, mostly due to road transportation of about 53\%; inland waterways are about 38\%, aviation by 9\%. Passenger transport increased on average (2010-2018) at about $12 \%$ / year, mostly due to road transportation around $97 \%$; inland waterway about $2 \%$, aviation about $1 \%$. If calculating all transport means operating in Ba Ria-Vung Tau province, it is estimated that in 2018: The total volume of goods transport will reach 18 million tons, passengers will reach about 47 million passengers ( $\underline{\mathrm{S}}$. Wang, Tang, He, Fukuyo, \& Azanza, 2008).

\section{Current status of cargo through group 5 seaport and Ba Ria-Vung Tau region}

According to the statistics of the Maritime Port Authorities and the Departments of Transport of Ho Chi Minh City, Dong Nai, and Ba Ria - Vung Tau, now the whole Group 5 has 51/104 dry cargo ports (including general department store, container and bulk cargo), reached an investment rate of about $49.0 \%$ (Table 1). In which: Dry cargo terminal (including general berth with container loading and unloading) currently has $42 / 92$ berths, accounting for $45.7 \%$; wharves under construction are 5/92 berths, accounting for 5.4\% and wharves under construction are 46/92 berths, accounting for 50.0\%. Existing specialized container terminals have $9 / 12$ berths, accounting for $75 \%$ ( $\mathrm{V}$. V. Pham, 2019a); The wharf under construction is $1 / 12$ wharves, accounting for $8.3 \%$ and the wharves under construction are $2 / 12$ wharves, accounting for $16.7 \%$ (J. Wang, 2017).

In terms of the size of receiving ships, some of Group 5 seaports now accommodate mother ships with a tonnage of over 10,000TEU, transport directly to European countries, the East Coast, the US West Coast, and Northern Europe without transshipment through intermediate ports in Singapore, Hong Kong, South Korea, and Thailand. In particular, CMIT port in Cai Mep has welcomed container ships with a tonnage of $157,000 D W T$, a capacity of 14,000 TEU (Slunge \& Tran, 2014). In terms of cargo throughput, the total cargo throughput of the Group 5 port in 2015 reached approximately 152,390 million tons, of which, containerized cargo stood at 7,229 million Teu. Dry and containerized cargoes are those products with high annual growth rates; in the period of 2011-2015, the dry cargo reached an average growth rate of $7.44 \% /$ year and container cargo achieved an average growth of $12.05 \%$ / year in tons and $11.49 \%$ / year in Teu (Tokody, Mezei, \& $\underline{\text { Schuster, 2017). }}$

Table 1: Container cargo throughput at seaports in Ba Ria Vung Tau province

\begin{tabular}{|c|c|c|c|c|c|c|c|}
\hline \multirow{2}{*}{ Category } & \multirow{2}{*}{ Unit } & \multicolumn{5}{|l|}{ Year } & \multirow{2}{*}{$\begin{array}{l}\text { Average } \\
\text { increase }\end{array}$} \\
\hline & & 2014 & 2015 & 2016 & 2017 & 2018 & \\
\hline \multirow{2}{*}{ Synthetic } & 103 Tons & 9.285 & 11.436 & 12.1982 & 13.4534 & 14.7086 & $22,74 \%$ \\
\hline & $10^{3}$ Teu & 1.154 & 1.356 & -181.04 & -414.75 & -648.47 & $22,64 \%$ \\
\hline \multirow{2}{*}{ Export } & $10^{3}$ Tons & 4.91 & 6.345 & 6.5974 & 7.2842 & 7.971 & $23,58 \%$ \\
\hline & $10^{3} \mathrm{Teu}$ & 552 & 701 & 733.6 & 807.6 & 881.6 & $22,26 \%$ \\
\hline \multirow{2}{*}{ Import } & $10^{3}$ Tons & 4.364 & 4.969 & 5.5092 & 6.058 & 6.6068 & $21,44 \%$ \\
\hline & $10^{3} \mathrm{Teu}$ & 601 & 641 & 736.9 & 814 & 891.1 & $23,51 \%$ \\
\hline \multirow[b]{2}{*}{ Inland } & $10^{3}$ Tons & 11 & 122 & 91 & 110.4 & 129.8 & $39,90 \%$ \\
\hline & $10^{3} \mathrm{Teu}$ & 1 & 15 & 9.3 & 10.8 & 12.3 & $9,69 \%$ \\
\hline
\end{tabular}

Source: Port Authority and Transport Departments of Ho Chi Minh City, Dong Nai, and Ba Ria - Vung Tau

\section{Shortcomings of transport infrastructure system connecting to Cai Mep Ha Logistics Center}

The Ba Ria - Vung Tau (BR-VT) seaport system has developed rapidly in recent years to support the seaport system in Ho Chi Minh City in order to promptly meet the rapidly increasing cargo volume in the past time. However, when the ports of Cai Mep - Thi Vai area are built and put into operation, the problem of shortcomings is that there is not a good transport connection infrastructure between these ports and regional industrial centers (X. Wang, Lin, \& Spencer, 2019). According to the Ministry of Transport, Cai Mep - Thi Vai port area only has about $15 \%$ of containers carrying out customs procedures at BR-VT and using the road, the remaining $85 \%$ still use barges to transport to Ho Chi Minh City and other areas for clearance. The reason for the low capacity of cargo transshipment through the port system in Cai Mep - Thi Vai area is the lack of synchronous traffic connection with the regional highways. On the other hand, due to the high cost of road transport, difficulties in transportation, many shippers do not dock at Cai Mep - Thi Vai port but transport goods by barges to other ports, which are convenient and cheaper. Meanwhile, the connection between the two expressways in the region is Long Thanh - Ben Luc, Trung Luong - Long Thanh - Dau Giay route with seaport group No. 5 (Southeast) is weak (Vahabzadeh \& Yusuff, 2015). 
Currently, technical infrastructure investment projects are arterial transport projects, supporting and promoting investment projects to build seaports ( $\mathrm{V}$. V. Pham, 2019b). However, in recent years and even now, the investment in transport infrastructure to serve seaports in Ba Ria - Vung Tau is incomplete; specifically, the ground clearance for construction of infrastructure projects is still very difficult (Ministry of Natural Resources and Environment, 2016). The transport electricity - water infrastructure system connecting the project implementation area is difficult, so the implementation of the port investment project is slow (Kontgis et al., 2014). The national highway 51 in Ba Ria - Vung Tau connecting to the seaport and the port's rear is not good and inconsistent with the port's capacity, leading to traffic congestion and wasting

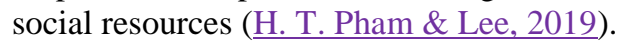

In particular, investment projects in transport infrastructure related to each other do not match the implementation schedule and the time of putting into operation. In fact, the current investment in the construction of seaport projects is carried out independently of transport infrastructure projects. Therefore, the completed seaport has not yet been smoothly connected with the road and rail transport system. The seaports currently do not have proper transport connections, which are not well connected with the financial system, banking, maritime logistics, logistics, and other services.

\section{FORECASTING DEMAND FOR TRAFFIC AREA IN THE PROJECT OF CA MEP HA PORT}

\section{The traffic demand forecast is based on a four-step model}

The McNally four-step forecasting method (Figure 2) consists of 1) generating- attracting the journey; 2) cruise distribution; 3) method division; 4) set route. The volume of traffic on the road after the forecast is that passengers and goods with existing travel demand have increased over time and the number of passengers has increased due to the ring road 3 connecting suburban areas of Ho Chi Minh City.

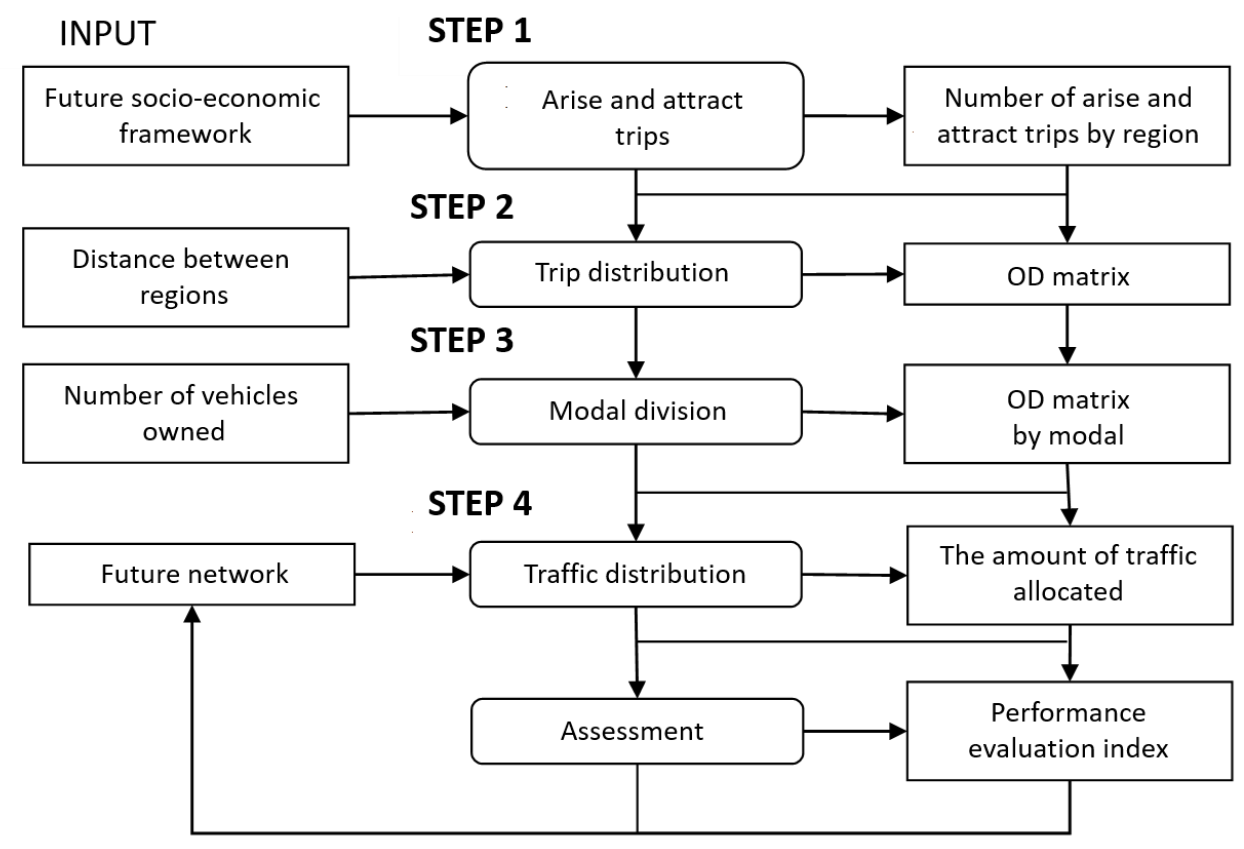

Figure 2: Traffic demand forecast process (Ruiz-Aguilar, Turias, \& Jiménez-Come, 2015)

\section{Sequence - results of traffic demand forecast}

Traffic volume on the master plan network is estimated by "transport allocation" using JICA STRADA software after estimating traffic demand for all vehicles between regions based on a 4-step method. In this step, the author only forecasts the number of passengers until 2030 in accordance with the socio-economic planning of Ba Ria - Vung Tau province.

\section{Step 1: Generate-attract the journey}

Predict the number of itineraries originating in 9 regions of BR-VT province and its vicinity (the zoning system is shown in Figure 3). Based on vehicle counting data to adjust the number of generated-attracted trips for the project-related areas in 2018 and calculate the forecasted years.

\section{Step 2: Distribute the journey}

The itinerary originating from each region in BR-VT province is determined to go to other regions with the number of specific trips forming the O-D matrix of the destination and destination of the forecasting model. Based on the 2018 road traffic volume, it is necessary to adjust the distribution of itineraries in the project affected areas and build the OD matrix in future years based on the elastic model method. 


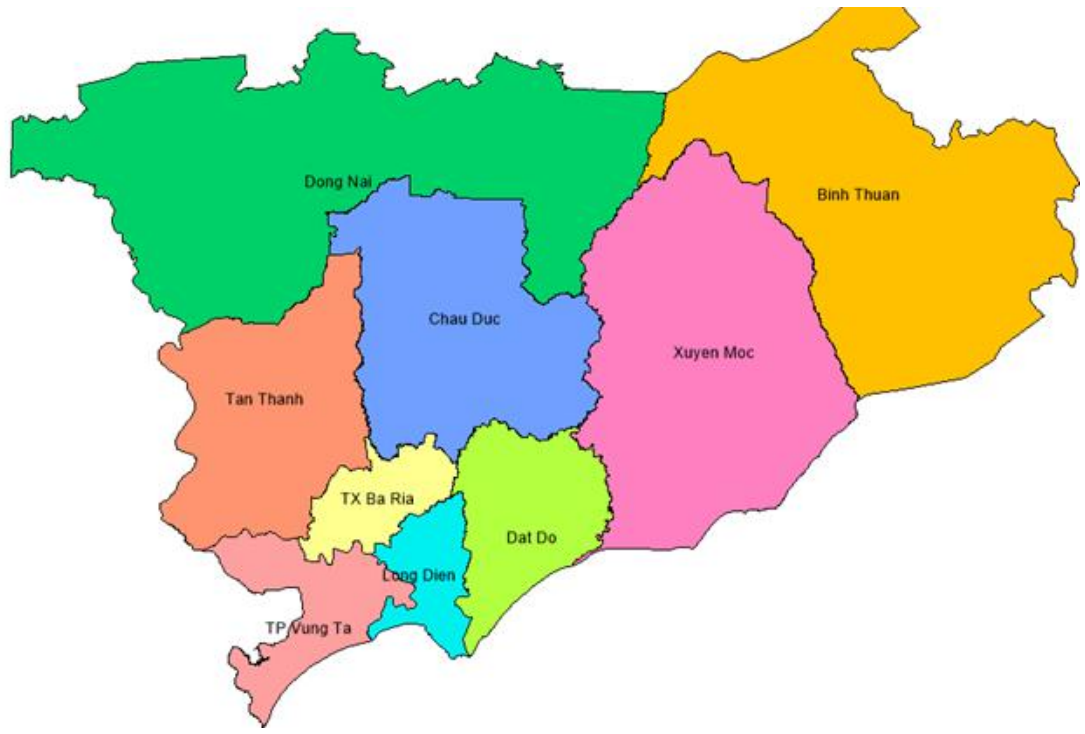

Figure 3: Map of the zoning system of the study area

\section{Step 3: Division of transport modes}

This study is based on the forecast of transport mode division of the BR-VT Provincial Transport Plan to 2020 and the orientation to 2030 to forecast the number of passengers using each type of transport. In addition, the author also based on collected vehicle survey data to serve as a basis for dividing transport modes.

\section{Step 4: Allocation of passenger traffic on the route}

Allocate traffic according to the principle of the shortest route and the minimum travel expenses for the journey to the transport network. The forecast thesis follows the traffic forecast model based on the modal matrix presented in step 3.

\section{Traffic demand forecast results}

\section{Results of traffic flow forecasting on the routes}

The forecast results in Table 2 show that the rate of vehicle traffic increases an average of $7 \%$ / year, of which the truck has the highest increase rate with $8.3 \%$. Figure 4 shows the results of the traffic forecast as an important parameter to determine and determine the transportation network to serve the development of logistics services in the future.

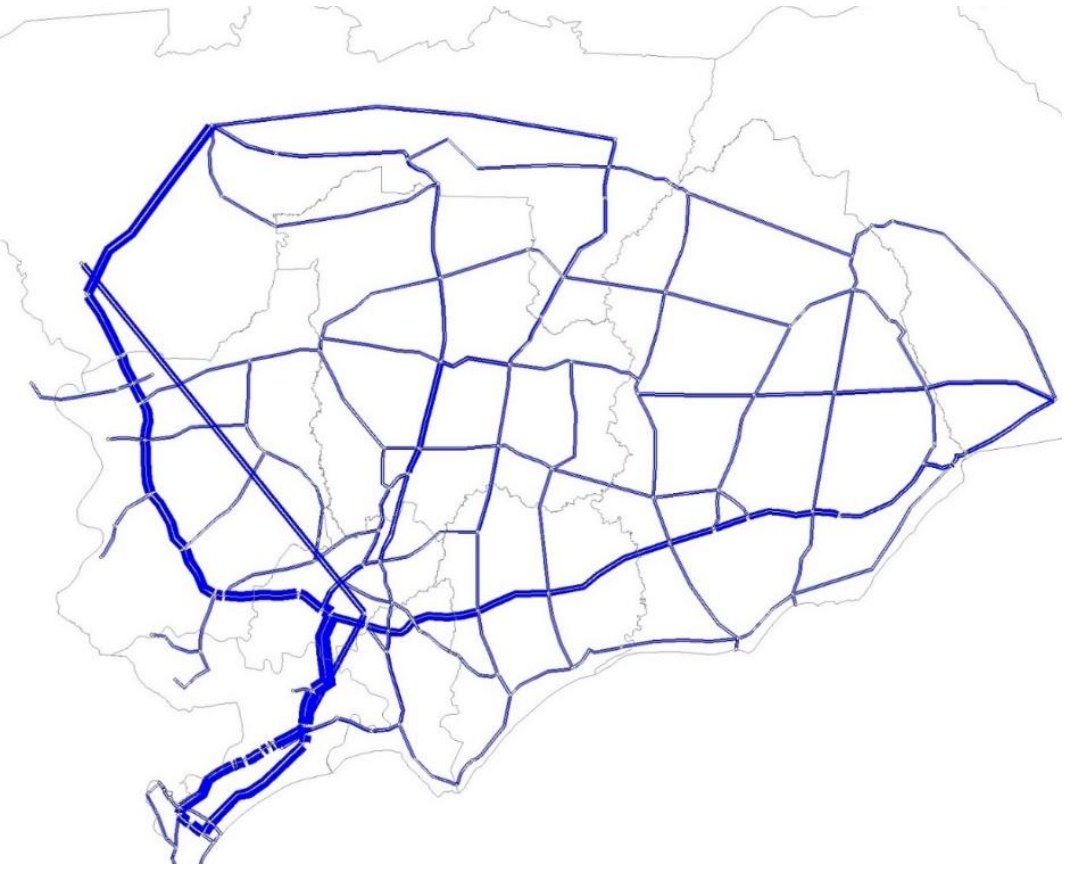

Figure 4: Traffic flow forecast result - PCU 
Table 2: Results of traffic volume forecast for 2030- PCU

\begin{tabular}{|c|c|c|c|}
\hline $\begin{array}{l}\text { Station name } \\
\text { (road) }\end{array}$ & Car counting position & Driving direction & Traffic flow \\
\hline \multirow{2}{*}{ Highway 51} & \multirow{2}{*}{$\begin{array}{l}\text { My Xuan Commune, Phu My } \\
\text { Town }\end{array}$} & Ba Ria $==>$ Sai Gon & 35.502 \\
\hline & & Sai Gon ==> Ba Ria & 37.323 \\
\hline \multirow{2}{*}{ Highway 56} & \multirow{2}{*}{ Hoa Long Ward, Ba Ria City } & Ba Ria ==> Chau Duc & 11.436 \\
\hline & & Chau Duc $==>$ Ba Ria & 10.820 \\
\hline \multirow{2}{*}{ Highway 55} & \multirow{2}{*}{$\begin{array}{l}\text { A Nhut Commune, Long Điền } \\
\text { District }\end{array}$} & Ba Ria City ==> Provincial road 52 & 9.817 \\
\hline & & Provincial road $52==>$ Ba Ria City & 9.238 \\
\hline \multirow{2}{*}{$\begin{array}{l}\text { Hoi Bai- Chau } \\
\text { Pha }\end{array}$} & \multirow{2}{*}{$\begin{array}{l}\text { Tan Hoa Commune, Phu My } \\
\text { Town }\end{array}$} & Highway $51==>$ Highway 56 & 8.774 \\
\hline & & Highway $56==>$ Highway 51 & 8.485 \\
\hline \multirow{2}{*}{$\begin{array}{l}\text { My Xuan-Ngai } \\
\text { Giao }\end{array}$} & \multirow{2}{*}{$\begin{array}{l}\text { My Xuan Commune, Phu My } \\
\text { Town }\end{array}$} & Highway 51 ==> Highway 56 & 9.528 \\
\hline & & Highway 56 ==> Highway 51 & 10.005 \\
\hline \multirow{2}{*}{$\begin{array}{l}\text { Road to Cai } \\
\text { Mep Port }\end{array}$} & \multirow{2}{*}{$\begin{array}{l}\text { Tan Phuoc Commune, Phu My } \\
\text { Town }\end{array}$} & Highway 51 ==> Cai Mep Port & 9.339 \\
\hline & & Cai Mep Port ==> Highway 51 & 9.678 \\
\hline
\end{tabular}

\section{Forecast of freight demand}

\section{Allocation of freight needs}

Current traffic demand allocation: Currently, there are 03 types of transportation in the study area: Road, inland waterway and airway. According to the aggregate data of $\mathrm{Ba}$ Tinh province, the freight transport output is distributed according to the transport sectors. Road: Accepting about $53 \%$ of the total transport demand. Inland waterways: Approximately $38 \%$ of the total transport demand. Aviation: Take care of about $9 \%$ of total transport needs (all goods exchanged between Vung Tau City with the rig and Con Dao).

The period to 2025: At this stage, there was no railway, so there were only 03 types of transport (road, inland waterway and aviation), of which road was still the main mode of transport. Road: Accepting about $65 \%$ of the total transport needs. Inland waterways: Approximately $30 \%$ of the total transport demand. Aviation: Take care of about $5 \%$ of the total transport demand (all goods exchanged between Vung Tau City with the rig and Con Dao).

The period to 2030: In this phase, the Ho Chi Minh City - Bien Hoa - Vung Tau City railway will be built and put into operation. Thus, the province will have 04 types of transport (road, inland waterways, aviation, and railways). Road: Ensuring about $50 \%$ of the total transport demand. Inland waterways: Approximately $30 \%$ of the total transport demand. Aviation: Take care of about $4 \%$ of total transport needs (all goods exchanged between Vung Tau City with the rig and Con Dao). Railway: Take up about $16 \%$ (on the corridor of Bien Hoa-Vung Tau).

\section{General forecast of goods quantities}

Based on the aggregated data on cargo throughput of the regional ports of port group 5 and BR-VT province, the author made a forecast of cargo by the elastic model method that shows: In the future, the volume of imports and exports through the seaport system in Vung Tau-Thi Vai area will increase quite high, at about 25\% in 2020 and 15\% in 2030. Since then the amount of goods circulating in the province of Ba Ria-Vung Tau has also increased, including Goods for production and consumption: forecast to increase to 6.8 million tons in 2020 and about 15.5 million tons in 2030. Goods imported and exported through the seaport system in Vung Tau-Thi Vai area: The port's capacity is ensured through the cargo demand: estimated in 19.7 to 21.0 million tons/year by 2020 ; in 2025 , about $32.4-35.1$ million tons/year; in 2030 , about $51.5-58.5$ million tons/year. In particular, the container is expected to be about $0.69-0.77$ million TEU / year by 2020 ; in 2025 , about 1.38 - 1.57 million TEU / year; in 2030, about 2.41 - 2.83 million TEUs / year.

\section{TRAFFIC PLANNING SOLUTIONS TO MEET THE DEVELOPMENT OF LOGISTICS TERMINAL SERVICES}

\section{The orientation of transport planning to meet the development of Cai Mep Ha port logistics service}

Promote the development of the transportation system, considering traffic as one of the driving forces for the economy's development. Sustainable and synchronous development of transport infrastructure: roads, waterways, seaports, airports, railways, system of wharves-bus stations, port system-inland wharves, ... meeting socio-economic development needs and ensuring national security and defense (Demirbas, 2017). Promote transport development to create conditions to promote the economic development of BR-VT province and the Southern key economic region, promoting the role of "gateway" of 
goods transshipment for the whole key economic region. Developing transportation to create conditions to attract and direct investment in areas where development is needed.

Roads: It is necessary to develop strongly the types of container transport and specialized means of transport; adopt policies to encourage enterprises to equip new and modern means and improve service quality; clearance and liquidation of old transport means, after the expiry of their service life (Chen, Tabssum, \& Nguyen, 2019).

Waterway: There should be a plan to exploit well the advantages of water transport. In addition to promoting the port system in Vung Tau-Thi Vai, it is necessary to plan and encourage investment in small ports to serve inland waterway transport. Planning routes, traffic routes, effectively exploiting routes: From the Province to Ho Chi Minh City, the Mekong River Delta provinces and other localities in Myanmar Central and the North and vice versa; the route from Vung Tau to Con Dao and other intra-provincial routes (Xu, Zhai, \& Phuong, 2019).

Railway: Under the Government's planning, the Ho Chi Minh City - Vung Tau railway will be invested. This will open up great prospects for transporting goods and passengers.

By air: With 2 small airports in Vung Tau and Con Dao, Air transport is still transporting tourists, transporting oil and gas workers and employees and transporting main commodities and materials serving the petroleum industry. Although the volume of goods and passengers is not much, due to the special nature of the object of transport and the type of operation, the implementation conditions ... (C. Wang et al., 2019). So air transportation still contributes to a significant proportion of the industry's revenue.

Orientations for development of port systems: The port system must be developed with the following objectives: (1) Support for Ho Chi Minh City ports and transshipment of goods for the Mekong River Delta, Southeast, and sub-regions. Mekong River; (2) Serving for industrial zones and export industries; (3) Contribute to increasing capacity of oil and gas service industry; (4) To form the largest port cluster in the South, meeting the demand for seaports and maritime in the region and the world. Modernizing the existing port system, making the most of the geographical conditions, river beds, and riverfront facades to build new ports. Establish a reasonable port system in terms of both capacity and tonnage (Aktas et al., 2019). In the next 5 years, there must be an additional port in the Thi Vai area and a container port in Cai Mep area to receive big ships of 20,000-80,000 tons. The estimated capacity to 2020 is 14.5 million tons/year and 2030 is 60 million tons/year. To prioritize construction first of all major general trading ports and specialized ports for containers. Building and developing ports is associated with the protection of the ecological environment, ecological forests and mangroves, without affecting the tourism potential of Ho Chi Minh City and Vung Tau City. To build a system of ports in sync with the construction of technical and social infrastructures, with urban development planning, especially traffic planning in the southern key economic region. In the development and operation of ports, it is necessary to closely combine economic development and defense requirements.

\section{Planning an external transport system for the logistics development}

\section{Road traffic system}

The planning orientation continues to promote the development of the transport system, considering traffic as one of the driving forces for the development of the economy. Main internal and inter-regional road transport routes have a strong influence on socio-economic development and especially to the operation of the seaport system in Ba Ria - Vung Tau province, including Highway 51; Bien Hoa - Vung Tau expressway; Cai Mep - Thi Vai Inter-port; Road 965; Highway 55; Highway 56; Tp. Ho Chi Minh - Long Thanh - Dau Giay; Southern Inter-regional expressway (Ring 4 - Ho Chi Minh City); East-West axis No. 1: My Xuan-Ngai Giao-Hoa Binh-Hoa Hoi-Binh Chau; East-West axis 2: Cai Mep-Hội Bai-Toc Tiên-Châu Pha-Stream Nghệ-Rock-Silver-Rao Rao-Xuyen Moc; Road connecting Long Son - Cai Mep.

\section{Port system}

Thi Vai-Cai Mep River is $42 \mathrm{~km}$ long, average depth is $10-20 \mathrm{~m}$, the average width is $600-800 \mathrm{~m}$ (widest to $1,000 \mathrm{~m}$ ) is an ideal condition to build a port system. Three possible areas for construction of ports are: In the Go Dau area, the width of the river bed is on average $300-400 \mathrm{~m}$, the average depth is about $10 \mathrm{~m}$, after straightening the curved section downstream, it can accommodate ships of 15,000DWT. In Phu My area, the river bed is on average $600 \mathrm{~m}$, the average depth is $15-20 \mathrm{~m}$, can accommodate ships of 30,000 - 50,000DWT. Cai Mep area, the average width of the river 800-1,000m, the average depth of 14-16m, can accommodate vessels 50,000-80,000DWT. In addition, Vung Tau also has a Dinh river of 12km, an average depth of 7-8m for vessels 10,000DWT in and out of Vietsopetro port. As such, both natural and economic conditions are very favorable for building a rich port system with high economic efficiency in Ba Ria-Vung Tau province.

Go Dau and Tac Ca Trung port areas: A wharf area for generalships and containers, capable of receiving ships of up to 30,000 tons. Phu My and My Xuan port areas (Thi Vai river): mainly for general cargo with a tonnage of 50,000 to 80,000 tons and container ships with a capacity of 4,000 to TEU. Continue to study the ability to renovate and expand the route to accommodate vessels of 60,000 - 120,000 tons (4,000 - 8,000 TEU) in Phu My and ships of up to 60,000 tons in My Xuan; There are a number of specialized wharves serving industrial and service establishments. 
Cai Mep, Sao Mai - Ben Dinh wharf areas are the main wharves of the port, mainly handling export and import container goods on far sea routes and international transshipment containers. Cai Mep area will receive ships of 80,000 - 100,000 tons (capacity of 6,000 - 8,000 TEU) and continue to study the possibility of improving the channel to receive ships of over 100,000 tons at Cai Mep. Why Sao Mai - Ben Dinh receives container ships from 80,000 tons (6,000 TEU capacity) to over 100,000 tons and has an international tourist port for ships of up to 100,000 GRT. Long Son port area: the main function is for special use of the petrochemical complex, with a wharf for importing crude oil for ships of 300,000 tons and wharves of 30,000 to 50,000 tons for importing other raw materials and producing products. The southeastern coast is used to build a general wharf for the long-term development of the region. Vung Tau - Song Dinh port area: to receive vessels of a tonnage of 10,000 tons (Dong Xuyen industrial park). Con Dao port area: the main function is a general wharf and passenger service for Con Dao, with ships of a tonnage of 2,000-5,000 tons. In addition, arranging maritime and petroleum service wharves for ships of up to 10,000 tons.

\section{Internal traffic planning to meet Logistics services in the port}

Planning the logistics center area

Landscape architecture space of the project with many works' items, diverse functions, but above all, it is organized to build an effective space, in accordance with the most important function of the project is the cargo transshipment areas, Logistics warehouse.

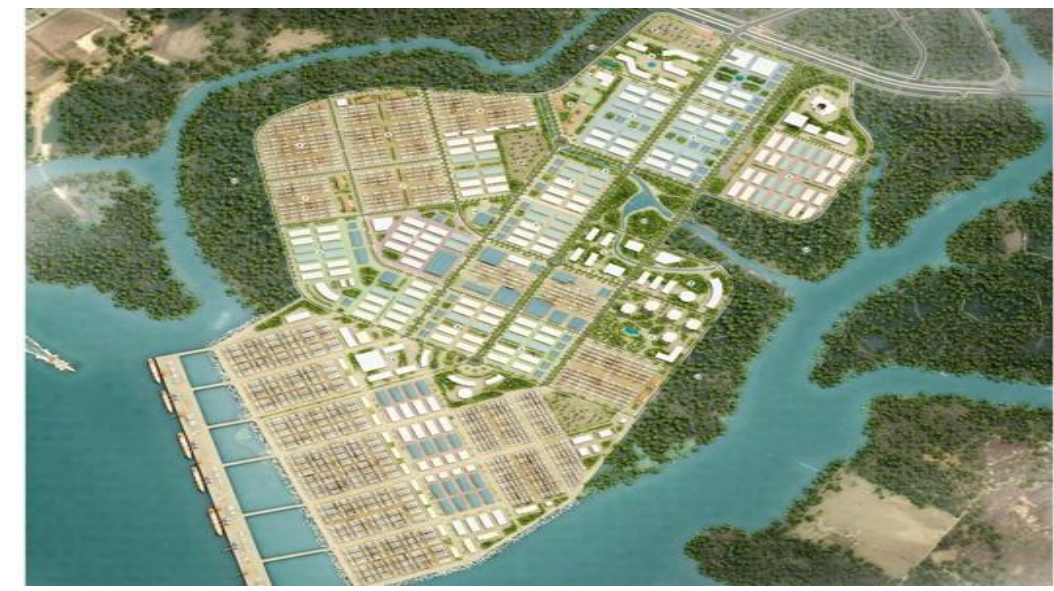

Figure 5: Cai Mep Ha port ground and logistics center

Logistics warehouse: The total area of the overall project is 180 ha with the proportion of the total project area: $30 \%$. Logistics depots are located close to the main axes of the project, convenient for transportation and freight. Square lots, easy to arrange works items such as warehouses, factories, temporary warehouses ... Logistics warehouses are designed to spread out from the port side to the inner side of the project, creating favorable conditions for decentralizing construction investment and calling for investment capital in stages.

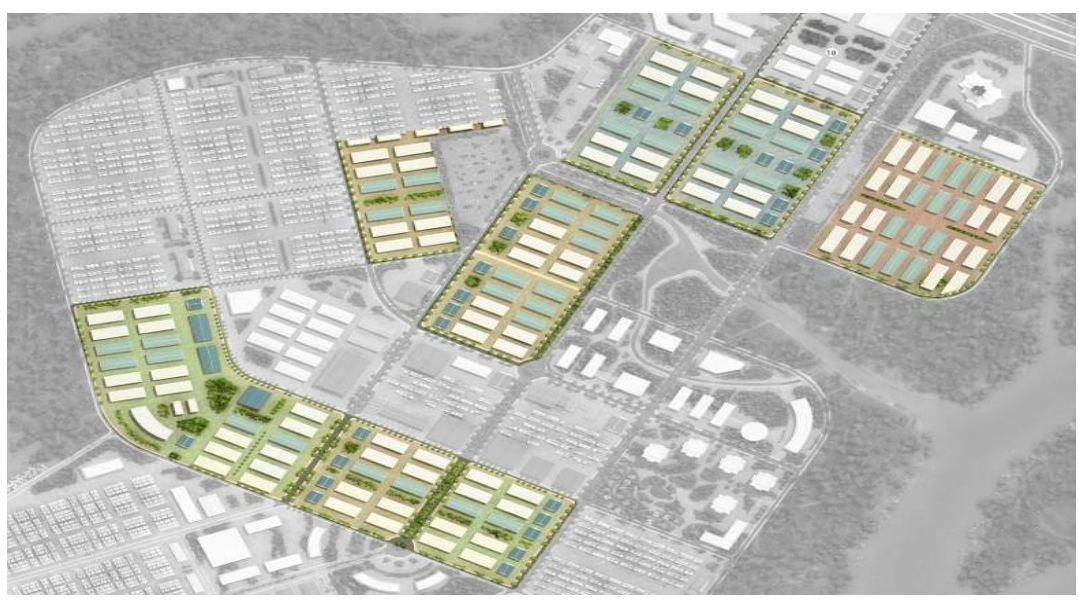

Figure 6: Arrangement of logistics warehouses

Container yards: The container yard includes the general cargo yard, empty container area, full and cold containers with a total area of 95 hectares, the area of the total project area is $15.87 \%$. Container depots are located near Logistics warehouses, creating favorable conditions for connecting freight. 


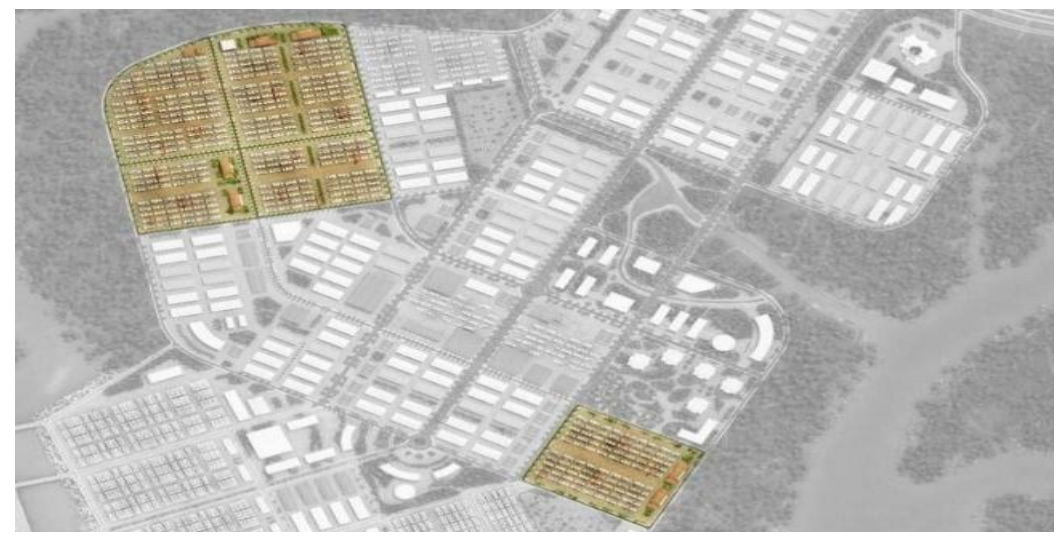

Figure 7: Location of container yards

Manufacturing area: The export processing zone consists of two areas with a total area of 29 ha located in the center of the project, near the port, close to the central road, which is convenient for transporting, importing and exporting goods after processing. ... The ratio of the export processing zone to the total project is $5 \%$.

Bonded warehouse: the Bonded warehouse is located near the future Cai Mep downstream, close to the main road, creating favorable conditions for transportation and storage of goods while waiting for import procedures. The total area of the project is 23.38 ha and the ratio of the area to the total project is $4 \%$.
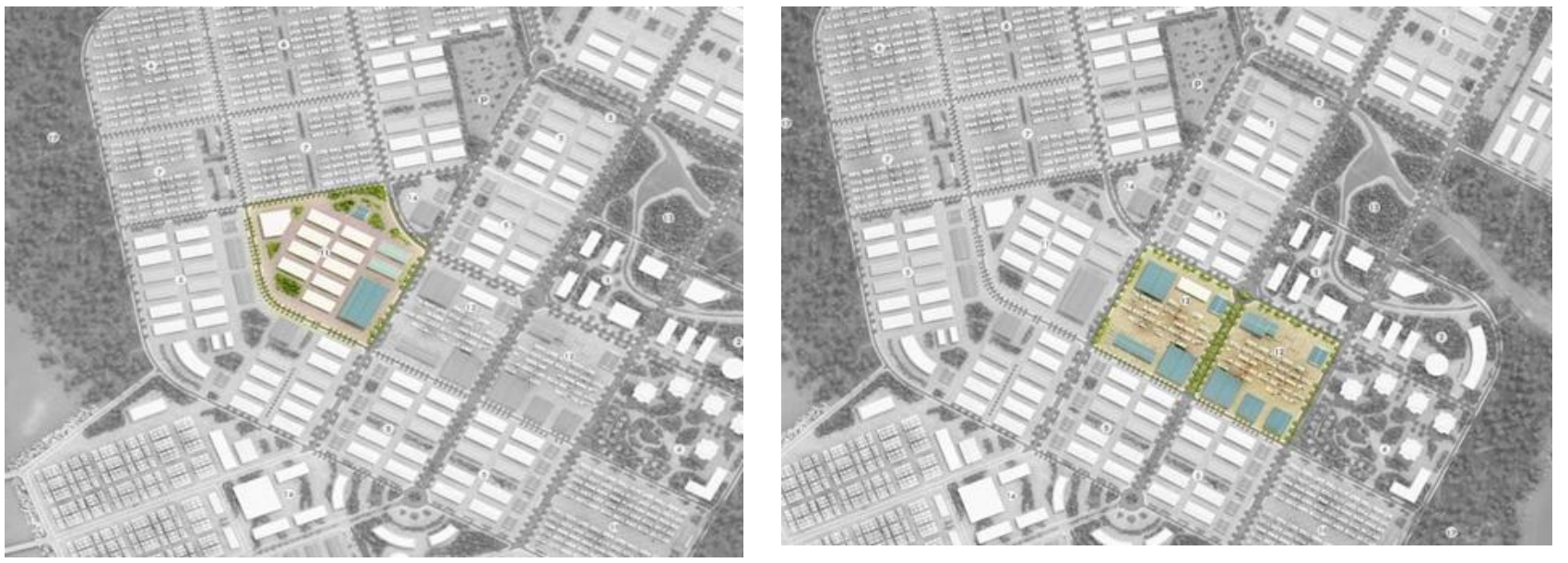

Figure 8: Location of bonded warehouse

Residential areas: Residential quarters consist of two main quarters, worker quarters and expert residences. For workers' quarters: arranged near parking lots, near main roads, creating favorable conditions for laborers to come to work. Inside the residential area, workers are fully built with social infrastructure such as kindergartens, gymnasiums, swimming pools ... to best serve the needs of workers' living. For expert housing areas, business areas: Being located near green parks, mangrove vegetation conservation areas with beautiful views. Inside the expert residence area (business area), there are many types of constructions such as villas, office towers, high-class apartments ... and the gymnasium such as swimming pool, tennis court, flower garden park ... forming a closed complex with high-class facilities.

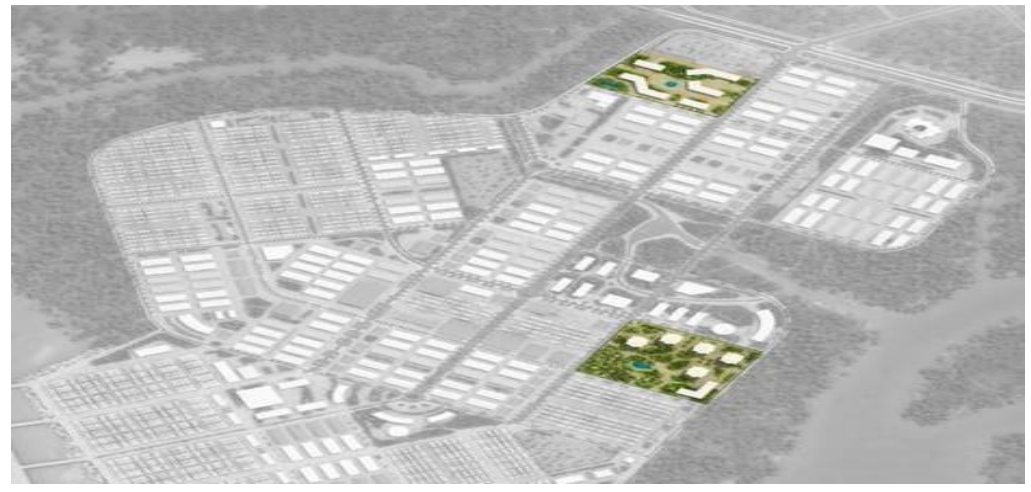

Figure 9: Housing for workers and specialists 


\section{Internal traffic planning}

According to the forecast for the demand for transport of goods by mode of transport: Water transport accounts for a large proportion with $65 \%$, rail transport is $25 \%$ and road transport accounts for $10 \%$. Therefore, it is necessary to build a synchronous transportation network with three main types of traffic: Roads, railways, waterways.

Road: Road system in Cai Mep port area is designed in the structure of a chessboard structure with a regional main axis and 2 main roads auxiliary areas running on both sides to ensure longitudinal connection. In addition, 5 horizontal axes ensure the connection of functional areas to the regional trunk road.

Railway: Constructing a branch railway to connect the study area with the Bien Hoa railway. Vung Tau and arranging cargo terminal at the center of the Logistics warehouse area. Goods from the Cai Mep port area and other functional areas are connected to the railway station by the $40 \mathrm{~m}$ main backbone and the $31 \mathrm{~m}$ regional main roads. The total length of the branch railway is about $6 \mathrm{~km}$, the section running within the study boundary is about $1 \mathrm{~km}$, the gauge is $1434 \mathrm{~mm}$ and the protection corridor is $5 \mathrm{~m}$ on each side.

Waterway: General port: To build a new Cai Mep general port area of about 350 ha in the south of the study area, adjacent to Ganh Rai Bay. The general port plays a major role in securing the transportation of $65 \%$ of the research area's cargo. Cai Mep's general port area is directly connected with the main road of the $40 \mathrm{~m}$ area to ensure the rotation of goods with other areas, especially the area of Logistics warehouse and railway station. Inland wharves system: Arranging inland wharves along Tac Lon river and Ong canal. In the areas of inland wharves, to build cargo depots to increase the capacity of waterway transport and play a complementary role for Cai Mep general port.

\section{CONCLUSION}

Transport is the lifeblood of the economy, and in the context of integration into the national transportation system, it must ensure that it meets the standards to improve the transport capacity in particular, logistics capacity in general, thereby improving the overall efficiency of the economy. To ensure the improvement of logistics efficiency through the development of transport infrastructure, it is necessary to synchronize the investment of the local territory and the Government. The development of transport infrastructure is a necessary issue in the period of national and regional economic development in the current integration period. The logistics system is built on the basis of a smooth transportation system that will improve socio-economic efficiency, create new incentives for sustainable regional economic development, developing the marine economy, raising the competitiveness of goods in the international market. Therefore, taking advantage of the advantages of geographical conditions, the development priority of the Party and the State to promote policies on developing transport infrastructure to serve logistics in order to maximize the potentials and advantages and towards highly competitive development, which has been a top priority of local authorities in recent years.

\section{THE IMPLICATIONS OF THIS STUDY AND FINDINGS}

The article has systematized the problems of port logistics and transport infrastructure to serve logistics. Provide some general theoretical issues about transportation for logistics services in general and for port logistics services in particular. Supplement, perfect the theoretical basis, give the concept of transport infrastructure to serve logistics. In addition, the authors also learn foreign and regional lessons learned to draw experience in the development process for the research area. In addition, the study analyzed the current situation of the transport system in Cai Mep Ha port area, including types of road, waterway, railway and air transport. Assessing the existence of transport infrastructure for logistics services in Cai Mep - Thi Vai port area; point out the shortcomings and inadequacies of transport infrastructure for logistics.

The Cai Mep - Thi Vai port area being invested and built and developed will be of utmost importance in Vietnam, with access to international maritime routes, connecting with existing wharves to form a continuous port system serving the dynamic economic development centers of the southern and international regions. Therefore, the planning and implementation of transport infrastructure construction as this analysis is important and necessary to increase connectivity with international transport routes, thereby contributing to improving the indicators of logistics capacity of the Ba Ria Vung Tau province in particular and raising the competitiveness of Vietnam compared to other countries in the region.

\section{ACKNOWLEDGMENT}

I would like to thank the College of Foreign Economic Relations (COFER) for supporting the author in compiling the data for this study.

\section{REFERENCES}

1. Agrawal, S., Singh, R. K., \& Murtaza, Q. (2015). A literature review and perspectives in reverse logistics. Resources, Conservation and Recycling, 97, 76-92. https://doi.org/10.1016/j.resconrec.2015.02.009

2. Aktaş, M., Sözen, A., Tuncer, A. D., Arslan, E., Koşan, M., \& Çürük, O. (2019). Energy-Exergy Analysis of A Novel Multi-Pass Solar Air Collector With Perforated Fins. International Journal of Renewable Energy Developments, 8(1), 47-55. https://doi.org/10.14710/ijred.8.1.47-55

3. Álvarez-SanJaime, Ó., Cantos-Sánchez, P., Moner-Colonques, R., \& Sempere-Monerris, J. J. (2013). Vertical integration and exclusivities in maritime freight transport. Transportation Research Part E: Logistics and 
Transportation Review. https://doi.org/10.1016/j.tre.2012.12.009

4. Chen, C., Tabssum, N., \& Nguyen, H. P. (2019). Study on Ancient Chu Town Urban Green Space Evolution and Ecological and Environmental Benefits. Nature Environment and Pollution Technology, 18(5), 1733-1738.

5. Demirbas, A. (2017). Tomorrow's biofuels: Goals and hopes. Energy Sources, Part A: Recovery, Utilization, and Environmental Effects, 39(7), 673-679. https://doi.org/10.1080/15567036.2016.1252815

6. Demirbas, A. (2016). Future energy systems. Energy Sources, Part A: Recovery, Utilization, and Environmental Effects, 38(12), 1721-1729. https://doi.org/10.1080/15567036.2014.962119

7. Dong, V. H., \& Phan, T. T. H. (2019). Solar power - A clean energy source that contributes to energy balance in Vietnam: A mini-review. Journal of Mechanical Engineering Research and Developments, 42(5), $177-181$. https://doi.org/10.26480/jmerd.05.2019.177.181

8. Govindan, K., \& Soleimani, H. (2017). A review of reverse logistics and closed-loop supply chains: a Journal of Cleaner Production focus. Journal of Cleaner Production, 142, 371-384. https://doi.org/10.1016/j.jclepro.2016.03.126

9. Hao Dong, T. M., \& Phuong Nguyen, X. (2019). Exhaust gas recovery from marine diesel engines in order to reduce the toxic emission and save energy: a mini-review. Journal of Mechanical Engineering Research \& Developments. https://doi.org/10.26480/jmerd.05.2019.143.147

10. Hoang, A. T., \& Pham, V. V. (2018). A review of fuels used for marine diesel engines. Journal of Mechanical Engineering Research \& Developments, 41(4), 22-32. https://doi.org/10.26480/jmerd.04.2018.22.32

11. Hoang, A. T., \& Pham, V. V. (2019). A study of emission characteristics, deposits, and lubrication oil degradation of a diesel engine running on preheated vegetable oil and diesel oil. Energy Sources, Part A: Recovery, Utilization, and Environmental Effects, 41(5), 611-625. https://doi.org/10.1080/15567036.2018.1520344

12. Khoa Pham, N. D., \& Phuong Nguyen, X. (2019). Application of CFD for calculation and simulation of anchorcable tensions in mooring ship. Journal of Mechanical Engineering Research \& Developments. https://doi.org/10.26480/jmerd.05.2019.182.186

13. Kontgis, C., Schneider, A., Fox, J., Saksena, S., Spencer, J. H., \& Castrence, M. (2014). Monitoring periurbanization in the greater Ho Chi Minh City metropolitan area. Applied Geography. https://doi.org/10.1016/j.apgeog.2014.06.029

14. Ministry of Natural Resources and Environment. (2016). National Policy on Biological Diversity 2016-2025. National Policy on Biological Diversity.

15. Nardin, W., Woodcock, C. E., \& Fagherazzi, S. (2016). Bottom sediments affect Sonneratia mangrove forests in the prograding Mekong delta, Vietnam. Estuarine, Coastal and Shelf Science. https://doi.org/10.1016/j.ecss.2016.04.019

16. Nguyen, T. T. (2016). An Investigation of the Vietnamese Shipping Industry and Policy Recommendations for Profound Participation into ASEAN Integration. The Asian Journal of Shipping and Logistics, 32(2), 81-88. https://doi.org/10.1016/j.ajs1.2016.05.001

17. Nguyen, X. P. (2019). The bus transportation issue and people's satisfaction with public transport in Ho Chi Minh city. Journal of Mechanical Engineering Research and Developments. https://doi.org/10.26480/jmerd.01.2019.10.16

18. Orchard, S. E., Stringer, L. C., \& Quinn, C. H. (2015). Impacts of aquaculture on social networks in the mangrove systems of northern Vietnam. Ocean and Coastal Management. https://doi.org/10.1016/j.ocecoaman.2015.05.019

19. Panigrahi, S. K., Kar, F. W., Fen, T. A., Hoe, L. K., \& Wong, M. (2018). A Strategic Initiative for Successful Reverse Logistics Management in Retail Industry. Global Business Review, 19(3_suppl), S151-S175. https://doi.org/10.1177/0972150918758096

20. Pham, H. T., \& Lee, H. (2019). Developing a Green Route Model for Dry Port Selection in Vietnam. The Asian Journal of Shipping and Logistics, 35(2), 96-107. https://doi.org/10.1016/j.ajs1.2019.06.002

21. Pham, V. T. (2019). Critical information for the Vietnamese economy aiming at a strategic breakthrough as approaching the industry 4.0. International Journal on Advanced Science, Engineering and Information Technology, 9(3), 1008-1016. https://doi.org/10.18517/ijaseit.9.3.8517

22. Pham, V. V. (2019a). Advanced technology solutions for treatment and control noxious emission of large marine diesel engines: A brief review. Journal of Mechanical Engineering Research and Developments ( JMERD ), 42(5), 21-27. https://doi.org/10.26480/jmerd.05.2019.21.27

23. Pham, V. V. (2019b). Research on the application of Diesel-Rk in the calculation and evaluation of technical and economic criteria of marine diesel engines using the unified ULSD and Biodiesel blended fuel. Journal of Mechanical Engineering Research and Developments, 42(2), 87-97. https://doi.org/10.26480/jmerd.02.2019.87.97

24. Phuong, N. H. (2019). What solutions should be applied to improve efficiency in the management of the port system in Ho Chi Minh City? International Journal of Innovation, Creativity and Change, 5(2), 1747-1769.

25. Ruiz-Aguilar, J. J., Turias, I. J., \& Jiménez-Come, M. J. (2015). A novel three-step procedure to forecast the inspection volume. Transportation Research Part C: Emerging Technologies. https://doi.org/10.1016/j.trc.2015.04.024

26. Shinde, K. D., \& Mane, P. B. (2019). Augmenting rooftop solar energy penetration ratio with secondary distribution network using a smart inverter for maximum power transfer capacity for subordinate grid- A review. 
Energy Sources, Part A: Recovery, Utilization, and Environmental Effects, 41(6), $713-733$. https://doi.org/10.1080/15567036.2018.1520353

27. Slunge, D., \& Tran, T. T. H. (2014). Challenges to institutionalizing strategic environmental assessment: The case of Vietnam. Environmental Impact Assessment Review. https://doi.org/10.1016/j.eiar.2014.05.005

28. Springer, C. (2018). Assessing energy intensity and retrofit opportunities for the aluminum industry: Lessons from Vietnam. Resources, Conservation and Recycling, 131, 235-246. https://doi.org/10.1016/j.resconrec.2017.12.020

29. Tokody, D., Mezei, I. J., \& Schuster, G. (2017). An overview of autonomous intelligent vehicle systems. InVehicle and Automotive Engineering (pp. 287-307). Springer. https://doi.org/10.1007/978-3-319-51189-4_27

30. Vahabzadeh, A. H., \& Yusuff, R. B. M. (2015). Content analysis in reverse logistics: A review. Journal of Statistics and Management Systems, 18(4), 329-379. https://doi.org/10.1080/09720510.2014.927605

31. Wang, C.-N., Day, J.-D., Lien, N., \& Chien, L. (2018). Integrating the Additive Seasonal Model and Super-SBM Model to Compute the Efficiency of Port Logistics Companies in Vietnam. Sustainability, 10(8), 2782. https://doi.org/10.3390/su10082782

32. Wang, C., Lu, W., Xi, C., \& Nguyen, X. P. (2019). Research on Green Building Energy Management Based on BIM and FM. Nature Environment and Pollution Technology, 18(5), 1641-1646.

33. Wang, J. (2017). Marine Protected Areas Network in the South China Sea: Charting a Course for Future Cooperation, written by Vu Hai Dang. The International Journal of Marine and Coastal Law, 32(2), $373-377$. https://doi.org/10.1163/15718085-12322050

34. Wang, S., Tang, D., He, F., Fukuyo, Y., \& Azanza, R. V. (2008). Occurrences of harmful algal blooms (HABs) associated with ocean environments in the South China Sea. Hydrobiologia, 596(1), 79-93. https://doi.org/10.1007/s10750-007-9059-4

35. Wang, X., Lin, X., \& Spencer, M. K. (2019). Exploring the effects of extrinsic motivation on consumer behaviors in social commerce: Revealing consumers' perceptions of social commerce benefits. International Journal of Information Management. https://doi.org/10.1016/j.ijinfomgt.2018.11.010

36. Witkowski, K. (2017). Internet of things, big data, industry 4.0-innovative solutions in logistics and supply chain management. Procedia Engineering, 182, 763-769. https://doi.org/10.1016/j.proeng.2017.03.197

37. Xu, Z., Zhai, S., \& Phuong, N. X. (2019). Research on Green Transition Development of Energy Enterprises Taking Mining Industry as an Example. Nature Environment and Pollution Technology, 18(5), 1512-1526. 